УДК 582.099:58.006

(C) 2016

Сиплива Н. О., кандидат біологічних наук,

Гненна М. О., старший науковий співробітник,

Коляденко С. С., старший науковий співробітник, Павленко О. В., науковий співробітник

Український інститут експертизи сортів рослин

\title{
ДЕКОРАТИВНІ ТРАВ'ЯНИСТІ РОСЛИНИ В УКРАЇНІ (ОСЕРЕДКИ КУЛЬТИВУВАННЯ, СТРУКТУРА, ДЕКОРАТИВНІСТЬ)
}

\section{Рецензент - кандидат сільськогосподарських наук М. І. Кулик}

\begin{abstract}
Подано кількісний та якісний склад декоративних трав'янистих рослин Державного Реєстру сортів рослин, придатних для поширення в Україні. Проаналізовано та узагальнено результати культивування декоративних трав'янистих рослин у ботанічних садах крайни. Здійснено таксономічний, географічний аналізи декоративних трав'янистих рослин та визначено показник оцінки їх декоративності. Відображено сорти декоративних трав'янистих рослин, які віднесено до групи рослин з високою декоративністю.
\end{abstract}

Ключові слова: арабатка, декоративні трав'янисті рослини, декоративність, ботанічний сад, культивування, міксбордер, сорт.

Постановка проблеми. Нині актуальними $\epsilon$ заходи $з$ покращання стану навколишнього середовища, благоустрою, озеленення міст і населених пунктів. У містобудуванні озеленення $\epsilon$ складовою частиною загального комплексу заходів щодо планування, забудови і впорядкування населених місць. Людина віддавна прагне прикрасити і свої оселі як зовні, так і всередині і в цьому ключова роль належить квітковим рослинам. Постійна зміна естетичних потреб людини вимагає оновлення і збагачення асортименту декоративних трав'янистих рослин. Важливо тільки грамотно підібрати рослини для створення і оформлення квітників. Окрім того, це сприятиме цілеспрямованій, результативній діяльності щодо збереження та збагачення сортового різноманіття трав'янистих рослин країни.

Аналіз основних досліджень і публікацій, у яких започатковано розв'язання проблеми. Декоративність рослин визначається сукупністю зовнішніх ознак: будовою і забарвленням листків, величиною і колоритом квіток, а також тривалістю цвітіння. Для досягнення декоративного ефекту, як додаткові до основних видів, застосовують різноманітні декоративні сорти, які зовнішніми ознаками значно відрізняються від характерних ознак виду $[5,10]$.

Джерелом цього є колекційні фонди інтродукова- них рослин та створення на їх базі нових високодекоративних сортів місцевої селекції, які $є$ найбільш пристосовані до конкретних умов зростання. Основними центрами збереження та збагачення біорізноманіття є власне ботанічні сади. Внаслідок чого зібрано значні колекційні фонди трав'янистих рослин, які вивчають та включають у селекційні програми, як донори генетичних ресурсів рослин [5, 10, 11].

Мета досліджень - виявити видову та сортову різноманітність декоративних трав'янистих рослин (ДТР) Реєстру та узагальнити місця їх культивування в Україні; визначити показник оцінки декоративності ДТР.

Об'єкт дослідження - види та сорти ДТР Реєстру.

Предмет дослідження - таксономічна, географічна структури ДТР, показник оцінки декоративності.

Відповідно до поставленої мети досліджень передбачалось вирішення наступних завдань:

1. Здійснити таксономічну, географічну структури ДТР Реєстру.

2. Виявити осередки культивування ДТР Реєстру.

3. Визначити показник оцінки декоративності трав'янистих рослин Реєстру для широкого їх використання в озелененні населених пунктів.

Матеріали та методика досліджень. Інвентаризацію трав'янистих рослин проводили методом камеральних досліджень, шляхом відбору видів та сортів зі списків, каталогів, Інтернетресурсів та інших опублікованих матеріалів. Для уточнення таксономічних назв ДТР використовували наукові видання С. К. Черепанова (1981) [13], латинські назви наведено за визначником рослин «Определитель высших растений Украины» (1999) [8]. Географічний аналіз здійснено за системою ботаніко-географічного поділу світу А. Л. Тахтаджяна (1978) [12]. Для визначення декоративності ДТР використали рекомендації О. А. Поради (2007) [10] з урахуванням наукових праць Р. В. Мельничука (2012) [9]. Ці автори пропонують за основу взяти декоративні особливості, а саме: висоту рослин, діаметр куща, забарвлення квіток, махровість суцвіття, діаметр 


\section{СІЛЬСЬКЕ ГОСПОДАРСТВО. РОСЛИННИЦТВО}

суцвіття, оригінальність та загальний стан рослин. Розрахунок вели за 9-бальною шкалою, тому за сумарної оцінки декоративності сорт максимально може отримати 54 бали. Для визначення декоративності ми скористалися наступною шкалою розподілу:

1 - декоративність слабка (оцінка менше 14 балів);

2 - декоративність посередня (оцінка від 15 до 28 балів);

3 - декоративність достатньо висока (оцінка від 29 до 41 балів);

4 - декоративність висока (оцінка від 42 до 54 балів).

Результати досліджень. За даними літературних джерел нами встановлено, що у Державному Реєстрі сортів рослин, придатних для поширення в Україні у 2016 році (Реєстр) підтримують 167 сортів декоративних трав'янистих рослин, які віднесено до 11 видів, 11 родів, 8 родин, одного відділу Magnoliophyta [3]. Нами встановлено, що більша кількість родин налічує у своєму складі по одному роду - 6 родин (Amaranthaceae, Cannaceae, Iridaceae, Paeoniaceae, Polemoniaceae, Saxifragaceae) (54,5 \% від загальної кількості родів).

За результатами досліджень встановлено, що найвищий ступінь сортової різноманітності відмічено у чотирьох родів: Paeonia L. - 36 сортів (22,0 \%), Chrysanthemum L. - 35 (21,0\%), Callistephus Cass. - 31 (18,5\%), Dahlia Cav. - 24 $(14,3 \%)$. Від 10 до 20 сортів нараховано у родів Gladiolus L., Hemerocallis L., Phlox L. тощо. Найбільшою видовою різноманітністю вирізняються родини: Asteraceae - три види (Dahlia Cav., Callistephus Cass., Chrysanthemum L.) та Liliaceae два види (Hemerocallis L., Tulipa L.).

Географічний аналіз показав, що ДТР Реєстру походять із двох підцарств Галарктичного царства: Давньосередземноморського, Бореального, котрі охоплюють чотири флористичні області. А також Неотропічного царства, яке займає тропічну Південну та Центральну Америку [12].

Відповідно до результатів географічного аналізу ДТР Реєстру представлені переважно видами iз різних природно-географічних зон земної кулі, які успішно пристосувалися до нових умов зростання. Найбільше видів зі Східноазійської області - чотири. Це види, які природно зростають у Китаї, Японії (Callistephus chinensis (L.) Nees, Astilbe Buch.-Ham.ex. D. Don., Hemerocallis $\times$ hybrida hort., Paeonia L.). По два види із Атлантико-Північноамериканської області (Dahlia $\times$ cultorum hort., Phlox paniculata L.) та Середземноморської області (Chrysanthemum $\times$ hortorum Bailey).
Унаслідок аналізу місць культивування видового та сортового різноманіття ДТР Реєстру виявлено, що у колекціях ботанічних садів України зростає 133 сорти, 7 видів, 7 родів, 5 родин, одного відділу Magnoliophyta, що становить 79,6 \% від загальної кількості сортів у Реєстрі [1, 2, 4-7].

Найвищу сортову різноманітність мають Chrysanthemum $\times$ hortorum Bailey - 32 сорти або 91,4 \% від загальної кількості сортів у Реєстрі), Paeonia L. - 35 (97,2 \%). На основі аналізу репрезентативності (кількість місць культивування) можна зробити висновок про склад видової та сортової різноманітності ДТР Реєстру в ботанічних садах України.

У результаті аналізу нами прийнято три ступеня репрезентативності: найвищий (6-7 видів ДТР Реєстру), середній (4-5), нижчий (1-3). Як показано в таблиці, найвищим ступенем видової та сортової репрезентативності характеризується Національний ботанічний сад імені М. М. Гришка НАНУ - 6 видів, 122 сорти (91,7 \% від загальної кількості сортів).

Серед них найвищою сортовою різноманітністю виділено Paeonia L. - 35 сортів (28,6 \% від загальної кількості представлених сортів): «Берегиня», «Червона Вежа», «Чаклунка», «Чебурашка», «Антей» та ін.; Chrysanthemum $\times$ hortorum Bailey 29 (23,7 \%): «Зірниця», «Оксамитка», «Смуглява красуня», «Осінній Блюз», «Перлинка» та ін.; Callistephus chinensis (L.) Nees - 23 сорти (18,8\%): «Фламінго», «Ангеліна», «Анжеліка», «Малиновий Блєск», «Анюточка» тощо. Від 6 до 18 сортів або 4,9-14,7 \% відповідно нараховано у Phlox paniculata L. -6 сортів, Gladiolus $\times$ hybridus hort. -11 , Dahlia $\times$ cultorum hort. -18 .

Середнім ступенем видової та сортової різноманітності характеризується Донецький ботанічний сад НАНУ - чотирма видами та 34 сортами (25,6 \%). Найбільшою кількістю сортів представлена Chrysanthemum x hortorum Bailey - 25 сортів (73,5 \% від загальної кількості представлених сортів): «Кассандра», «Белая Ромашка», «Бархан», «Хрустальна», «Колискова» та інші. Трьома сортами $(8,8$ \%) вирізняються Callistephus chinensis (L.) Nees, Dahlia $\times$ cultorum hort., Hemerocallis $\times$ hybrida hort. У колекціях ботанічного саду Чернівецького національного університету імені Юрія Федьковича нараховано чотири види та 25 сортів (18,7\%), серед яких 12 сортів (48,0\%) Chrysanthemum $\times$ hortorum Bailey - «3вездопад», «Лелія», «Кнопа», «Умка», «Привітна» та інші. Від одного до 8 сортів представлено Dahlia $\times$ cultorum hort. - один сорт, Phlox paniculata L. - чотири, Gladiolus $\times$ hybridus hort. - вісім. 
СІЛЬСЬКЕ ГОСПОДАРСТВО. РОСЛИННИЦТВО

Ступінь представленості сортів ДТР Реєстру в колекціях ботанічних садів

\begin{tabular}{|c|c|c|c|}
\hline Назва виду & $\begin{array}{c}\text { Кількість } \\
\text { сортів у Реєстрі, } \\
\text { шт. }\end{array}$ & $\begin{array}{c}\text { Кількість } \\
\text { сортів у колек- } \\
\text { ціях БС, шт. }\end{array}$ & Місце культивування \\
\hline Astilbe Buch.-Ham.ex. D. Don. & 4 & - & - \\
\hline Callistephus chinensis (L.) Nees & 31 & 23 & $1-2,9-10,13$ \\
\hline Canna indica L. & 1 & - & - \\
\hline Chrysanthemum $\times$ hortorum Bailey & 35 & 32 & $1-3,4,7,9-10,11,12$, \\
\hline Dahlia $\times$ cultorum hort. & 24 & 20 & $13-14$ \\
\hline Gladiolus $\times$ hybridus hort. & 13 & 11 & $1,3,4,6-7$ \\
\hline Hemerocallis $\times$ hybrida hort. & 10 & 3 & 2 \\
\hline Paeonia L. & 36 & 35 & $1,3,10,11$ \\
\hline Phlox paniculata L. & 10 & 8 & $1,4,7,10$ \\
\hline Tulipa hybrida hort. & 2 & - & - \\
\hline Celosia cristata L. & 1 & - & - \\
\hline Pasom: & 167 & 133 & \\
\hline
\end{tabular}

Умовні позначення: БС - ботанічний сад, НДЛ - науково-дослідна лабораторія, ННЦ - навчально-науковий центр, 1 - Національний ботанічний сад імені М. М. Гришка НАНУ, 2 - Донецький ботанічний сад НАНУ, 3 - Криворізький ботанічний сад НАНУ, 4 - БС Дніпропетровського національного університету, 5 - БС «Волинь» Волинського державного університету імені Л. Українки, $\mathbf{6}$ - БС Черкаського національного університету імені Б. Хмельницького, 7 - БС Чернівецького національного університету імені Ю. Федьковича, 8 - БС Подільського державного аграрно-технічного університету; 9 - БС Харківського національного університету імені В. Н. Каразіна, 10 - БС Львівського національного університету імені І. Франка, 11 - Запорізький міський дитячий ботанічний сад, 12 - БС Одеського національного університету імені I. І. Мечникова, 13 - НДЛ «Ботанічний сад» ННЦ «Інститут біології» Київського національного університету імені Т. Шевченка, 14 - БС Національного лісотехнічного університету України.

У ботанічному саду Львівського національного університету імені І. Франка культивується чотири види, 16 сортів (12,0\%). Найвищою сортовою різноманітністю вирізняється Chrysanthemum $\times$ hortorum Bailey -8 (50,0\%): «Крижинка», «Вродлива», «Привітна», «Пектораль», «Золоте Руно».

Криворізький ботанічний сад НАНУ, Ботанічний сад Дніпропетровського національного університету, Ботанічний сад «Волинь» Волинського державного університету імені Л. Українки, Ботанічний сад Черкаського національного університету імені Б. Хмельницького, Ботанічний сад Подільського державного аграрно-технічного університету, Ботанічний сад Харківського національного університету імені В. Н. Каразіна та інші характеризуються нижчим ступенем представленості видів ДТР (один-три види) та від 1 до 21 сорту, що становить 0,6-12,5\% відповідно. Лише одним видом (одним або двома сортами) представлені ДТР у Ботанічному саду Одеського національного університету імені I. I. Мечникова - Chrysanthemum $\times$ hortorum Bailey «Промениста», «Сонечко», Ботанічному саду Черкаського національного університету імені Б. Хмельницького - Dahlia $\times$ cultorum hort. «Вечный огонь», Ботанічному саду Подільського державного аграрнотехнічного університету - Gladiolus $\times$ hybridus hort.

«Мираж».

Створення гармонійної системи поєднання рослинних форм, сортів $\epsilon$ головною метою озеленення. Широкий спектр декоративних якостей видів ДТР дає можливість їх вмілого поєднання в озелененні міських зон. Тому одним із завдань наших досліджень було визначення показників оцінки декоративності сортів ДТР. Для визначення декоративності нами були відібрані нові сорти видів ДТР, що занесені до Реєстру за останні три роки. Це такі: Chrysanthemum $\times$ hortorum Bailey - вісім сортів, Hemerocallis $\times$ hybrida hort. - шість сортів, Callistephus chinensis (L.) Nees - чотири сорти.

За результатами оцінки декоративності сорти, які віднесено до групи, що мають достатньо високу декоративність, нараховано 14 або 77,7 \% від загальної кількості досліджуваних сортів (рис. 1), показник оцінки декоративності яких коливається в межах від 29 до 41 балу. Як показали результати наших досліджень, до групи 3 високою декоративністю можна віднести чотири сорти ДТР. Це два сорти Callistephus chinensis (L.) Nees - «Янтарна» - 46 балів, «Анжеліка» - 48 балів та по одному сорту Chrysanthemum $\times$ hortorum Bailey - «Осінній блюз» 48 балів; Hemerocallis $\times$ hybrida hort. - «Сливовий коктейль» -42 бали. 


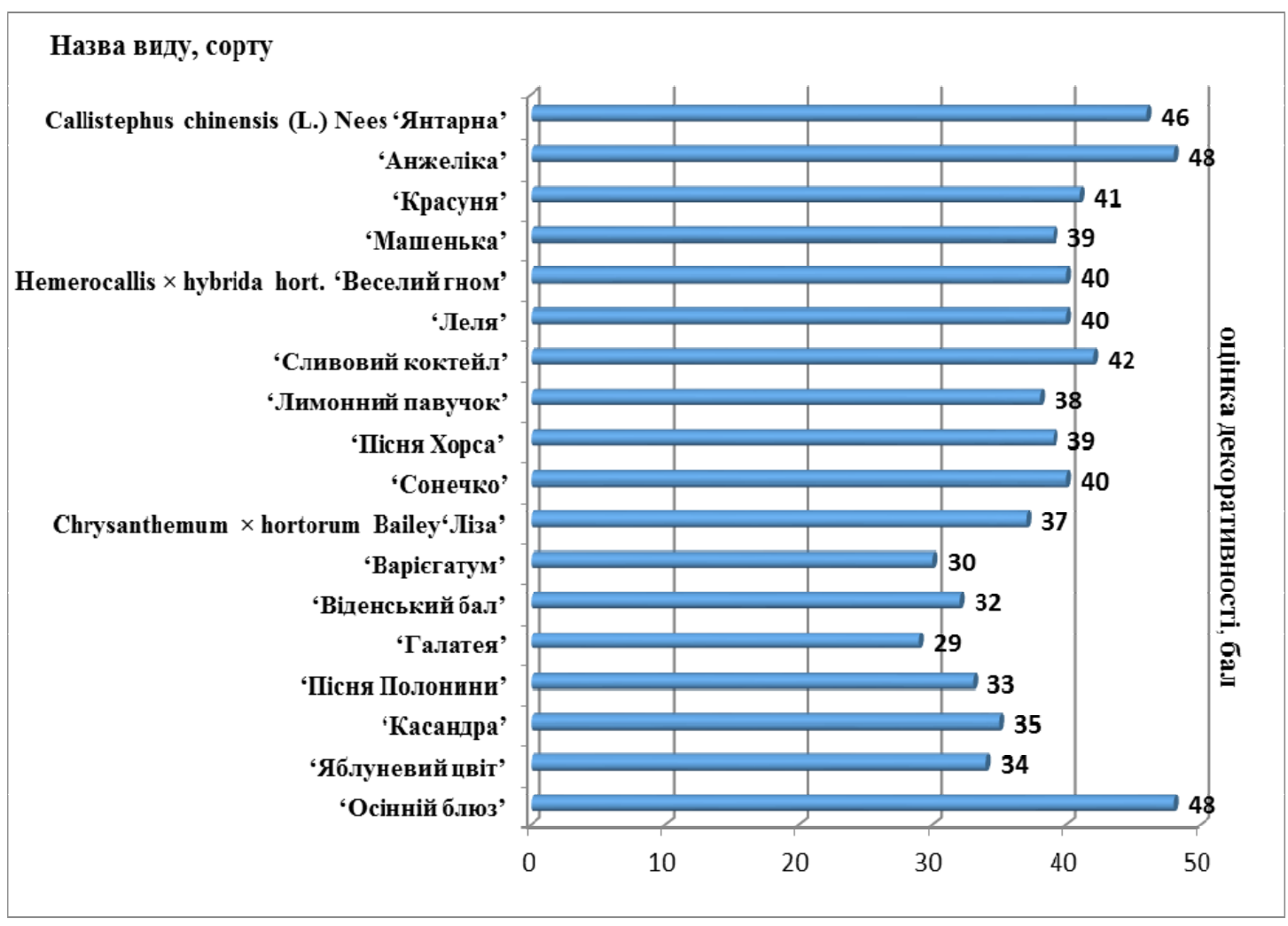

Рис. 1. Амплітуда показників оцінки декоративності ДТР Реєстру

ДТР є достатньо, середньо та високо декоративними і придатні до використання як на зріз, так і для озеленення населених пунктів і присадибних ділянок. Асортимент ДТР залежить від того, яке цільове призначення матиме садовопарковий об'єкт, за якими архітектурнопланувальними принципами ці об'єкти будуть створені: клумби, рабатки, міксбордери, групи, солітери. Для створення клумб придатні сорти видів Callistephus chinensis (L.) Nees, Chrysanthemum $\times$ hortorum Bailey, Tulipa hybrida hort., Celosia cristata L., рабаток - Canna indica L.,

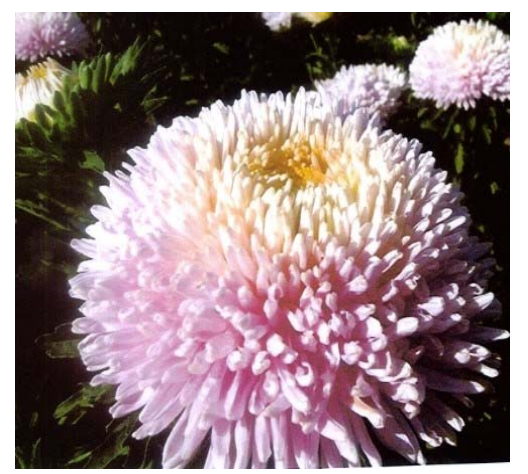

Puc. 2. Callistephus chinensis (L.) Nees сорт «Янтарна"
Gladiolus $\times$ hybridus hort., міксбордерів - Phlox paniculata L., Astilbe Buch.-Ham.ex. D. Don. Декоративні солітери або групи можна створити, використовуючи сорти видів Paeonia L., Chrysanthemum $\times$ hortorum Bailey, Hemerocallis $\times$ hybrida hort. тощо.

На рис. 2, рис. 3 , рис. 4 та рис. 5 відображено сорти рослин ДТР, які, на нашу думку, віднесено до групи високодекоративні, показник оцінки декоративності яких коливається в межах від 42 до 48 балів.

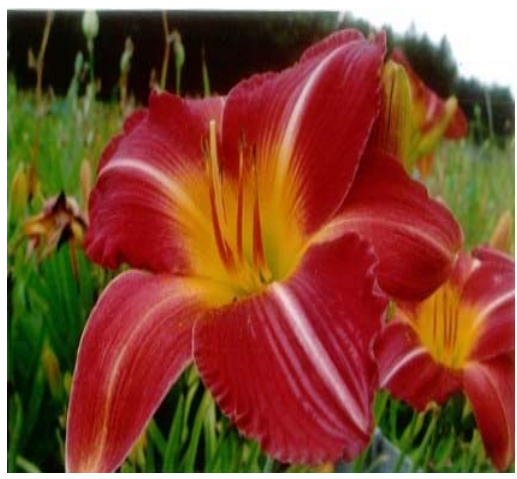

Puc. 3. Hemerocallis $\times$ hybrida hort. сорт «Сливовий коктейль» 


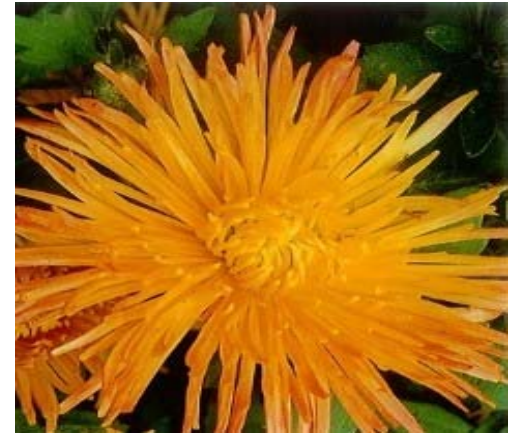

Puc. 4. Chrysanthemum $\times$ hortorum Bailey сорт «Осінній блюз»

Висновок. Результатами наших досліджень встановлено, що у Реєстрі підтримують 167 сортів ДТР. Аналіз осередків культивування ДТР Реєстру показав, що у колекціях ботанічних садів України зростає 133 сорти, 7 видів, 7 родів, 5 родин, одного відділу Magnoliophyta. Найвищим та середнім ступенем репрезентативності ДТР Реєстру вирізняються Національний ботанічний сад імені М. М. Гришка НАНУ - 122 сорти $(91,7 \%)$, Донецький ботанічний сад НАНУ - 34 $(25,6 \%)$, Ботанічний сад Чернівецького націона-

\section{БІБЛІОГРАФІЯ}

1. Ботанічний сад Полтавського державного педагогічного університету ім. В. Г. Короленка : путівник / [уклад. : Оніпко В. В., Гриньова М. В., Дзюбаненко А. С., Гапон С. В.]. - Полтава : Полтавський держ. педагогічний ун-т ім. В. Г. Короленка, АСМI, 2003. - 27 с.

2. Глухов О. 3. Донецький ботанічний сад Національної академії наук України : путівник / О. З. Глухов, О. М. Шевчук. - Донецьк : ДедраСхід, 2002. - 128 с.

3. Державний реєстр сортів рослин, придатних для поширення в Україні у 2016 році. - [Чинний станом на 05.05.2016] [Електронний ресурс]. Режим доступу: http://minagro.gov.ua/system /files/Реєстр сортів.pdf.

4. Каталог рослин Ботанічного саду Національного лісотехнічного університету України : довідник / [за ред. П. Р. Третяка]. - Львів : вид-во Нац. ун-ту «Львівська політехніка», 2006. - 60 с.

5. Каталог декоративних трав'янистих рослин ботанічних садів і дендропарків України : довідниковий посібник [Електронний ресурс] / за ред. С. П. Машковської. - К. : [б. в.], 2015. - 282 с. Режим доступу : http://www.nbg.kiev.ua/upload /biblio/katalog.pdf.

6. Каталог растений Криворожского ботанического сада : справ. пособие / [Бойко Л. И., Василенко Е. В., Вечканова Л. В., Доровская И. А.,

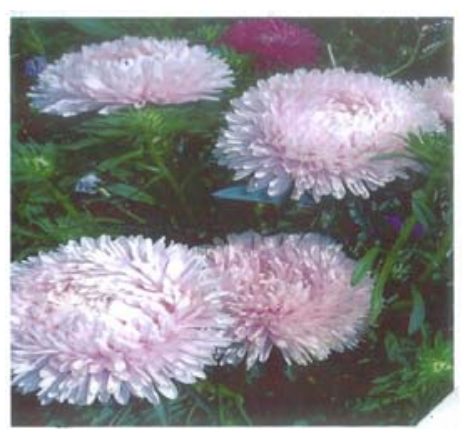

Puc. 5. Callistephus chinensis (L.) Nees
copm «Анжеліка»

льного університету імені Юрія Федьковича -25 $(18,7 \%)$, Ботанічний сад Львівського національного університету імені I. Франка - 16 (12,0 \%). За результатами оцінки декоративності до групи, що мають достатньо високу декоративність віднесено 14 сортів ДТР (або 77,7 \%), а до групи 3 високою декоративністю віднесено чотири сорти $(22,3 \%)$ - Callistephus chinensis (L.) Nees - «Янтарна», «Анжеліка», Chrysanthemum $\times$ hortorum Bailey - «Осінній блюз», Hemerocallis $\times$ hybrida hort. - «Сливовий коктейль».

Калинчук Л. Н.]. - К. : Фитосоциоцентр, НАН Украины, Криворож. ботан. сад, 2000. - 164 с.

7. Колекція рослин Ботанічного саду Дніпропетровського національного університету / [Опанасенко В. Ф., Зайцева О. І., Кабар А. М., Сироватко К. О., Мартинова Н. В.]. - Дніпропетровськ : Дніпропетр. нац. ун-т, РВВ ДНУ, 2008. - 224 с.

8. Котов М. И. Определитель высших растений Украины / М. И. Котов, Ю.Н.Прокудин, А. И. Барбарич. - [2-е изд., стереот., с незнач. доп. и испр.]. - К. : Фитосоциоцентр, Акад. наук Украинской ССР, Ин-т ботаники им. Н. Г. Холодного, 1999. - $548 \mathrm{c}$.

9. Мельничук Р. В. Оцінка декоративності зразків колекції роду Calendula L. / Р. В. Мельничук // Вiсті Біосферного заповідника «АсканіяНова». - 2012. - Т. 14. - С. 516-518.

10. Порада О. А. Методика формування та ведення колекцій лікарських рослин / О. А. Порада. - Полтава : ПП ПДАА, 2007. - 50 с.

11. Рубиова О. Л. Підсумки інтродукції старовинних троянд у Національному ботанічному саду імені М. М. Гришка НАНУ / О. Л. Рубцова, В. І. Чижанькова // Сортовивчення та охорона прав на сорти рослин. - 2016. - №2. - С. 5-9.

12. Тахтаджян А. Л. Флористические области Земли / А. Л. Тахтаджян. - Л. : Наука, 1978. - 247 с.

13. Черепанов С. К. Сосудистые растения СССР / С. К. Черепанов. - Л. : Наука, 1981. - 510 с. 